\title{
Effect of Ethidium Bromide (EB) and N-methyl-N'-Nitro-N-Nitrosoguanidine (NTG) on Metabolic Activities of Streptomyces Strain N-404
}

\author{
Ismail Saadoun $^{1 *}$ and Hazem Haddad ${ }^{2}$ \\ ${ }^{1}$ Department of Applied Biology, College of Sciences, University of Sharjah, Sharjah, UAE \\ ${ }^{2}$ Princes Haya Center for Biotechnology, Jordan University of Science and Technology, \\ Irbid- 22110, Jordan \\ *Corresponding author
}

\section{A B S T R A C T}

Keywords

Aerial mycelium, bald mutant,

Antibiotic,

Enzyme, Streptomyces

Article Info

\section{Accepted:}

29 June 2017

Available Online:

10 July 2017
In this report, an attempt to study the effect of production of inhibitory bioactive compounds and fiber hydrolytic enzymes was demonstrated by mutagenic agent treatment analysis. The effects of two chemical mutagenic agents [N-methyl-N'-nitro-N-nitrosoguanidine (NTG) $(65-500 \mu \mathrm{g} / \mathrm{ml})$ and Ethidium Bromide (EB) $(5-25 \mu \mathrm{M})]$ on the loss of enzymes and antibiotic activities and generation of bald mutants (no aerial mycelia) in Streptomyces strain N-404, were observed. Generation of bald mutants was observed with treatment with $65 \mu \mathrm{g} / \mathrm{ml}$ of NTG and $10 \mu \mathrm{M}$ EB after 5 and 14 days, respectively. Production of antibiotics and fiber hydrolytic enzymes (amylase, cellulase, and xylanase) was not eliminated, but noticeable reduction of these activities in the mutant strain was detected.

\section{Introduction}

Members of the genus Streptomyces produce two-thirds of the naturally occurring antibiotics worldwide (Berdy, 1995), with streptomycetes being the best known enzyme producers (Vinogradova and Kushnir, 2003). These Gram-positive soil bacteria undergo a complex cycle of morphological differentiation. They produce extensive branching of vegetative hyphae and aerial mycelia on solid media which give the colony its leathery or powdery appearance. Upon maturity, aerial mycelia form chains of spores (Anderson and Wellington, 2001). Several studies have been conducted to investigate the effect of physical and chemical mutagenic agents on the alteration in the regular colony morphology of Streptomyces spp. and how this change in morphology is linked with the production of secondary metabolites. These agents are also responsible for the production of bald mutants (loss of formation of aerial mycelia). For example, treatment of Streptomyces species with ethidium bromide (EB), acriflavine (AF), or acridine orange (AO) can generate "bald" mutants which have lost the ability to sporulate and may also lack the ability to synthesize off-flavor compounds (Redshaw et al., 1976; Redshaw et al., 1979). Saadoun et al., (1998) showed the formation of bald mutants and loss of aerial mycelia 
$\left(\mathrm{amy}^{-}\right)$after treatment of Streptomyces halstedii and Streptomyces violaceusniger with EB and NTG.

In this communication, the effects of two curing agents [Ethidium Bromide (EB) and Nmethyl-N'-nitro-N-nitrosoguanidine (NTG)] on growth response, production of enzymes and antibiotics as well as loss of its morphology and aerial mycelium by Streptomyces strain $\mathrm{N}-404$ is reported. Therefore, the purpose of this work is to ascertain whether enzymes/antibiotics production is affected after mutation treatment.

\section{Materials and Methods}

Streptomyces spp. (N-404 strain) an antibiotic active-producing isolate was used in this study. The isolate was previously recovered from soil in the Northern Jordan and shown to be active against multi-drug resistant pathogens.

\section{Preparation of spore suspension}

Spore suspension of Streptomyces strain N404 was freshly prepared or frozen in $20 \%$ glycerol according to Hopwood (1985). Culture of N-404 strain was grown on Hickey-Tresner (HT) (Hickey and Tresner 1952) agar ( $\mathrm{pH} 7.3)$ for 10 days at $28^{\circ} \mathrm{C}$. The spores were harvested by scraping, suspended in $0.1 \%$ Tween 80 , then vortexed for $9 \mathrm{~min}$ at room temperature. The suspension was filtered through glass wool and Whatman \#1 filter paper, and the spore pellet was suspended in $20 \%$ glycerol.

\section{Protoplast preparation}

Briefly, $0.1 \mathrm{ml}$ of fresh or frozen spore suspension of Streptomyces N-404 strain was inoculated into $25 \mathrm{ml}$ yeast extract malt extract (YEME) broth, incubated at $\left(30^{\circ} \mathrm{C} / 200 \mathrm{rpm}\right)$ for $36-40 \mathrm{hr}$, then centrifuged at $\left(30^{\circ} \mathrm{C} / 200 \mathrm{rpm}\right)$ for $10 \mathrm{~min}$. Pellet was suspended in $15 \mathrm{ml}$ of $10.3 \%$ sucrose, and then centrifuged at $\left(30^{\circ} \mathrm{C} / 200 \mathrm{rpm}\right)$. After that, the pellet was re-suspended in $4 \mathrm{ml}$ of lysozyme solution $(2 \mathrm{mg} / \mathrm{ml})$ in protoplast buffer, followed by incubation at $30^{\circ} \mathrm{C} / 20$ min, and then by addition of $5 \mathrm{ml}$ protoplast buffer. Finally, the protoplast buffer was filtered through cotton wool and centrifuged at $(3000 \mathrm{rpm} / 7 \mathrm{~min})$, and then the pellet was suspended in protoplast buffer and kept in eppendorf tubes $-70^{\circ} \mathrm{C}$ (Blatz and Matsushima, 1983).

\section{Treatment with chemical mutagens}

Stocks for the chemical mutagenic agents [Nmethyl-N'-nitro-N-nitrosoguanidine (NTG) and Ethidium Bromide (EB) were prepared in $0.05 \mathrm{M}$ Tris Malieic (TM) buffer, and the $\mathrm{pH}$ was adjusted to 8. Crystals of both mutagenic agents were vigorously vortexed until dissolved, filtered through Millipore size filter $(0.45 \mu \mathrm{m})$, then incubated at $30^{\circ} \mathrm{C}$ for $1-2$ hours (Delic et al., 1970).

Disrupting enzymes/antibiotic activities and alteration in morphology was attempted by inoculating the spore suspension into $100 \mathrm{ml}$ flasks containing $25 \mathrm{ml}$ HT broth. The mutagenic agents were added to Streptomyces $\mathrm{N}-404$ cultures to achieve the required concentration $(65-500 \mu \mathrm{g} / \mathrm{ml})$ and 5-25 $\mu \mathrm{M}$ for [N-methyl-N'-nitro-N-nitrosoguanidine (NTG) and Ethidium Bromide (EB), respectively. Control flasks receive no mutagenic agents. Broth cultures were incubated at $28{ }^{\circ} \mathrm{C} / 200 \mathrm{rpm}$ for 14 days. After observing growth at 1, 2, 3, 5, 10, and 14 days intervals, serial dilutions were plated onto HT agar medium, and plates were incubated for $48 \mathrm{hr}$ at $28^{\circ} \mathrm{C}$. Presumptive aerial myceliumnegative $\left(\mathrm{amy}^{-}\right)$colonies were picked aseptically and re-plated onto HT agar medium under the same conditions. 
Testing for enzymatic activities by agar diffusion method

The wild type and mutated culture of Streptomyces N-404 strain was tested for amylase, cellulase, and xylanase enzymes production. The isolate was cultured on agar media having $1 \%$ of each carbon sources (Nanmori et al., 1990).

\section{Testing for amylase- production}

Pure isolate of Streptomyces N-404 is cultured on starch casein nitrate agar (SCNA) and incubated at $28^{\circ} \mathrm{C}$ for 3-4 days. The plates were then flooded with Gram's iodine solution and left for 5 minutes, then washed with distilled water. Bacterial colonies producing amylase show clear zone against black color of stained starch (Santos and Martins, 2003).

\section{Testing for cellulase- production}

Pure isolate of Streptomyces N-404 is cultured on cellulose agar of the following composition $(\mathrm{g} / \mathrm{L})$ yeast extract: $1 \mathrm{~g}$; CMC (carboxy methyl cellulose): $10 \mathrm{~g} ; \mathrm{KH}_{2} \mathrm{PO}_{4}: 4$ $\mathrm{g} ; \mathrm{NaCl}: 2 \mathrm{~g} ; \mathrm{MgSO}_{4} .7 \mathrm{H}_{2} \mathrm{O}: 1 \mathrm{~g} ; \mathrm{MnSO}_{4}: 0.05$ g; $\mathrm{FeSO} 4.7 \mathrm{H}_{2} \mathrm{O}: 0.05 \mathrm{~g} ; \mathrm{CaCl}_{2} .2 \mathrm{H}_{2} \mathrm{O}: 2 \mathrm{~g}$; $\mathrm{NH}_{4} \mathrm{Cl}: 2 \mathrm{~g}$ and agar: $20 \mathrm{~g}$; $\mathrm{pH}$ 7-7.2. Plates were incubated at $28^{\circ} \mathrm{C}$ for 4 days and then flooded with $0.1 \%$ Congo red and left for 15 $20 \mathrm{~min}$, washed with $1 \mathrm{ml} \mathrm{NaCl}(1 \mathrm{M})$ and left for $15 \mathrm{~min}$. Bacterial colonies producing cellulase show clear zones against red color of non-hydrolyzed media (Sharma et al., 1990). Positive isolates were tested again to confirm cellulase production.

\section{Testing for xylanase-production}

Pure isolate of Streptomyces N-404 is cultured on xylan agar of the following composition $(\mathrm{g} / \mathrm{L})$ yeast extract: $1 \mathrm{~g}$; xylan: 10 g; $\mathrm{KH}_{2} \mathrm{PO}_{4}: 4 \mathrm{~g} ; \mathrm{NaCl}: 2 \mathrm{~g} ; \mathrm{MgSO}_{4} .7 \mathrm{H}_{2} \mathrm{O}: 1$ g; $\mathrm{MnSO}_{4}: 0.05 \mathrm{~g} ; \mathrm{FeSO} 4.7 \mathrm{H}_{2} \mathrm{O}: 0.05 \mathrm{~g}$; $\mathrm{CaCl}_{2} \cdot 2 \mathrm{H}_{2} \mathrm{O}: 2 \mathrm{~g} ; \mathrm{NH}_{4} \mathrm{Cl}: 2 \mathrm{~g}$ and agar: $15 \mathrm{~g}$; $\mathrm{pH}$ 7-7.2. Plates were incubated at $28^{\circ} \mathrm{C}$ for 4 days. The plates were then flooded with absolute ethanol (99\%) and left for 1 hour at room temperature. Colonies producing xylanase enzyme show clear zones against an opaque color of non-hydrolyzed media (Priest, 1985). Positive activity is tested again for confirmation.

\section{Antimicrobial activity by agar disc diffusion method}

This was tested by the Bauer-Kirby method (Bauer et al., 1966) against Staphylococcus aureus and Escherichia coli. Each tested microbe was grown in $250 \mathrm{ml}$ Erlenmeyer flask containing $50 \mathrm{ml}$ of nutrient broth (Himedia/India) (pH 7.2) with overnight shaking at $100 \mathrm{rpm}$ and $37{ }^{\circ} \mathrm{C}$. Turbidity of organisms in the broth was adjusted to be equal to or greater than 0.5 McFarland turbidity standards $\left(1.5 \times 10^{8} \mathrm{cfu} / \mathrm{ml}\right)$. The test organisms were homogeneously inoculated by a sterile cotton swab on the surface of two freshly prepared Mueller-Hinton agar (Himedia, India) then 3 agar discs (5 $\mathrm{mm}$ in diameter) were cut out from each wild type and mutagenic agent treated Streptomyces N404 culture that has been grown on HT agar medium at $28{ }^{\circ} \mathrm{C} \pm$ for 10 days (Saadoun $e t$ al., 1998); and then transferred by a flamesterilized needle to be placed onto the surface of Mueller-Hinton agar plates. Plates that were seeded only by the tested pathogens were considered as negative controls. Plates were then incubated at $28{ }^{\circ} \mathrm{C} \pm 1$. Inhibition zones were visually detected after $24 \mathrm{~h}$.

\section{Results and Discussion}

Attempts were made to generate bald mutants by treatment of Streptomyces N-404 protoplasts with dyes. When the mutated Streptomyces N-404 protoplasts were 
compared with the untreated ones, data indicated a weak growth response in HT broth even at the lowest applied concentration of each of EB $(5 \mu \mathrm{M})$ and NTG $(65 \mu \mathrm{g} / \mathrm{ml})$ (Table 1). Growth response of the mutated protoplasts was followed in HT broth and our observations indicated the formation of long threads with no spherical shape beads (Fig. 1A). These mutants generated in the submerged cultures after treatment with mutagenic agents were called in this study as "Submerged mutants" (SMs) and characterized by irregular growth as has often been reported in Streptomyces species (Yamazaki et. al., 2003a, 2003b; Kato et. al., 2005). On HT agar surface, the parental Streptomyces N-404 wild-type colonies were characterized by long chains of spores and white powdery appearance (Fig. 2A). However, colonies derived by treatment of Streptomyces N-404 protoplasts with $5 \mu \mathrm{M}$ (EB) for 14 days appeared soft and the formation of aerial mycelium is critically affected that resulted in generation of bald mutants and loss of aerial mycelia (amy-) (Fig. 2B). This loss of aerial mycelia after dye treatment has often been reported in Streptomyces species (Ikeda et. al 1981; Hopwood et al., 1973; Redshaw et al., 1976;
Sermonti et al., 1980; Saadoun et al., 1998). Redshaw et al., (1979) suggested that treatment of Streptomyces species with mutagenic agents such as ethidium bromide (EB), acriflavine (AF), and acridine orange (AO) may responsible for the production of bald mutants (loss of formation of aerial mycelia).

Streptomyces N404 strain showed the potential to degraded starch, cellulose, and xylan (Table 2) as indicated by the clear zones around the colonies. Data indicated the wild type and mutated colonies produce the three tested enzymes; amylase, cellulase, and xylanase (Fig. 3). The three tested enzymes were maintained by both bald and SMs after treatment with the dyes.

Streptomyces N-404 exhibited an antibiotic activity against Staphylococcus aureus and Escherichia coli with $9 \mathrm{~mm}$ inhibition zone diameter (Table 2) and (Fig. 4). Production of inhibitory metabolites by the bald mutants generated in this study was not eliminated, but was reduced (Fig. 4C), and this may explain the linkage gene of these two processes and the involvement of linked genes on the chromosome (Saadoun et al., 1998).

Table. 1 Generation of bald mutants and growth response of Streptomyces N-404 strain in HT broth after treatment with EB and NTG chemical mutagenic agents

\begin{tabular}{lccccccccc}
\hline Time (Days) & \multicolumn{10}{c}{ Mutagenic Agent } \\
\hline \multicolumn{9}{c}{ EB $(\mu \mathrm{M})$} & \multicolumn{7}{c}{ NTG $(\mu \mathrm{g} / \mathrm{ml})$} \\
\hline 1 & 0 & 5 & 10 & 25 & 0 & 65 & 130 & 250 & 500 \\
2 & ND $^{\mathrm{a}}$ & ND & ND & ND & ND & ND & ND & ND & ND \\
3 & $+{ }^{\mathrm{b}}$ & ND & ND & ND & + & ND & ND & ND & ND \\
5 & ++ & ND & ND & ND & ++ & ND & ND & ND & ND \\
10 & +++ & ND & ND & ND & +++ & + & ND & ND & ND \\
14 & +++ & ND & ND & ND & +++ & ND & ND & ND & ND \\
\hline
\end{tabular}

a ND: Not detected.

${ }^{\mathrm{b}}$ Growth response: +: Weak; ++: Moderate; +++: Strong 
Table.2 Inhibitory metabolites and degradation activities of wild type and mutant Streptomyces N-404

\begin{tabular}{cccccc}
\hline Culture & \multicolumn{3}{c}{ Enzyme } & & \multicolumn{2}{c}{ Antibiosis (mm Inhibition Zone Diameter) } \\
& Amylase & Cellulase & Xylanase & S. aureus & E. coli \\
\hline Wild type & + & + & + & 9 & 9 \\
Bald mutant & + & + & + & 9 (No Clear Zone) & 9 (No Clear Zone) \\
SMs & + & + & + & 9 & 9 \\
\hline
\end{tabular}

Fig.1 Streptomyces N-404 strain grown in HT broth and treated with mutagenic agents. A: Submerged mutants (SMs) after treatment with $65 \mu \mathrm{g} / \mathrm{l}$ (NTG); B: Wild type

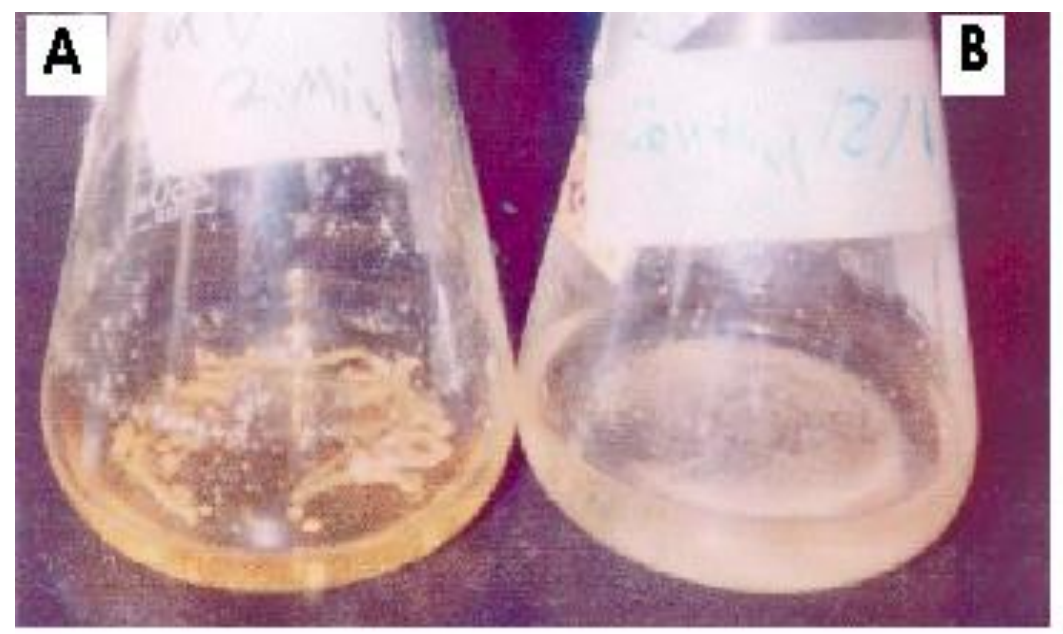

Fig.2 Treatment Streptomyces N-404 colonies on HT agar surface with ethidium bromide (EB). (A) Wild type; (B) Bald mutant after treatment with $5 \mu \mathrm{M}$ EB for 14 days
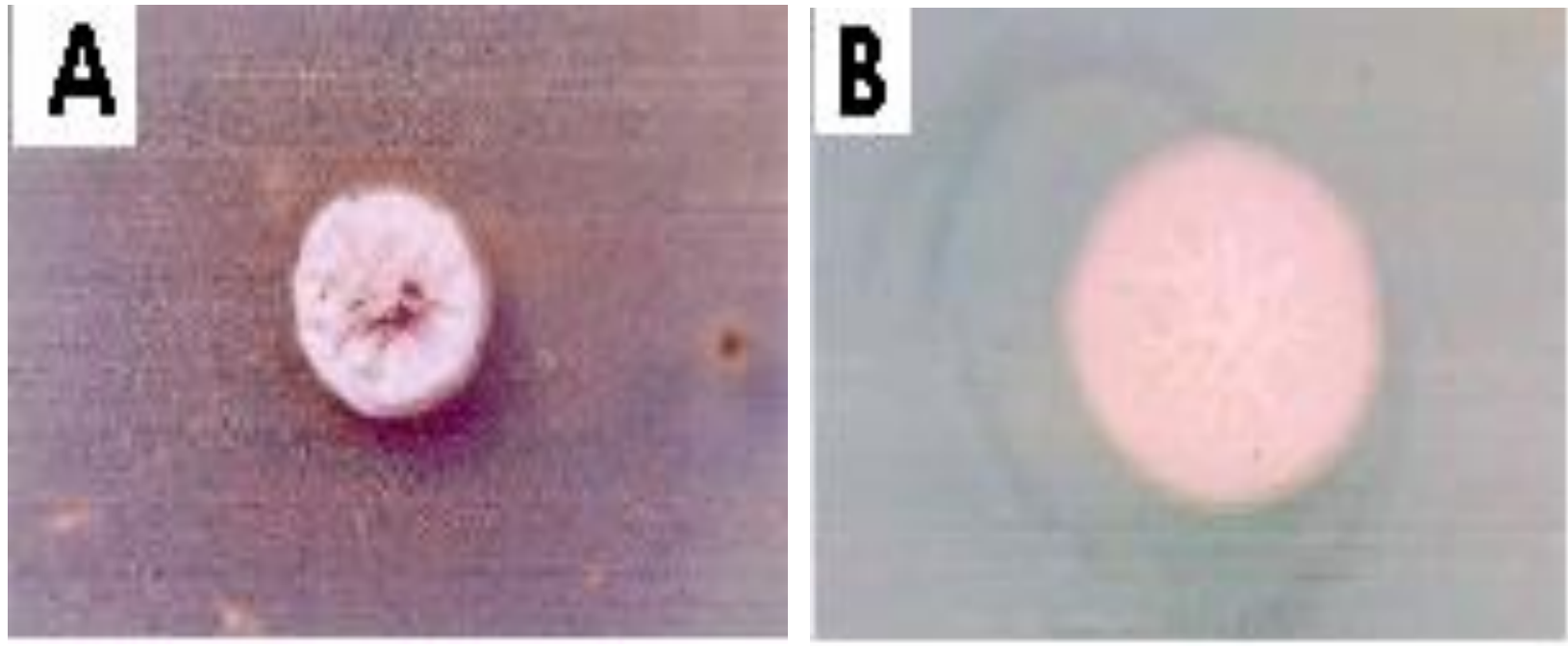
Fig.3 Testing for (1) cellulase; (2) xylanase; and (3) amylase production by Streptomyces N-404 cultures treated with $5 \mu \mathrm{M}$ EB. A: Wild type; B: Bald mutants, C: Submerged mutants (SMs)
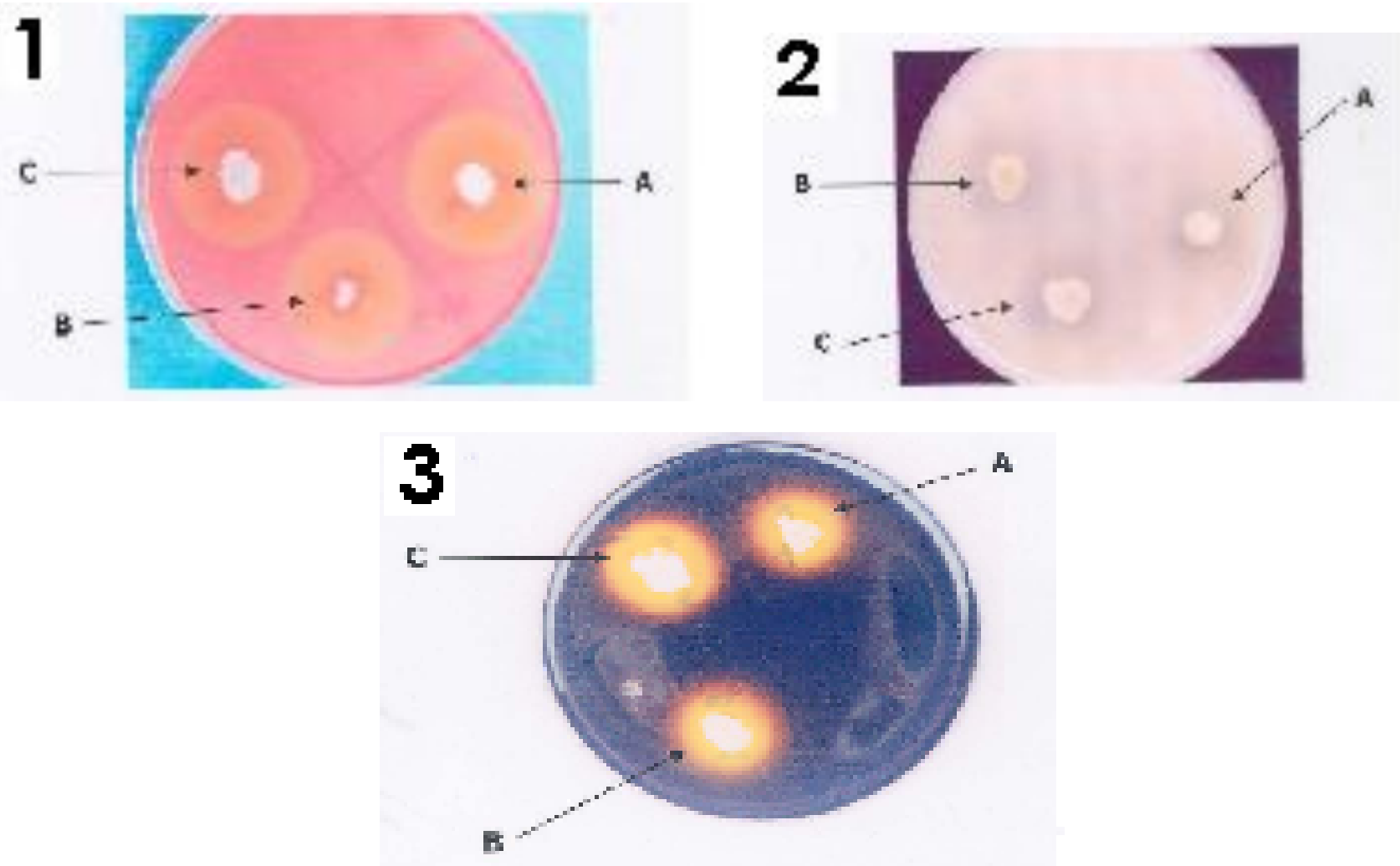

Fig.4 Testing for antibiosis by Streptomyces N-404 cultures against Staphylococcus aureus. A: Wild type; B: Bald mutant; C: Submerged mutants (SMs)

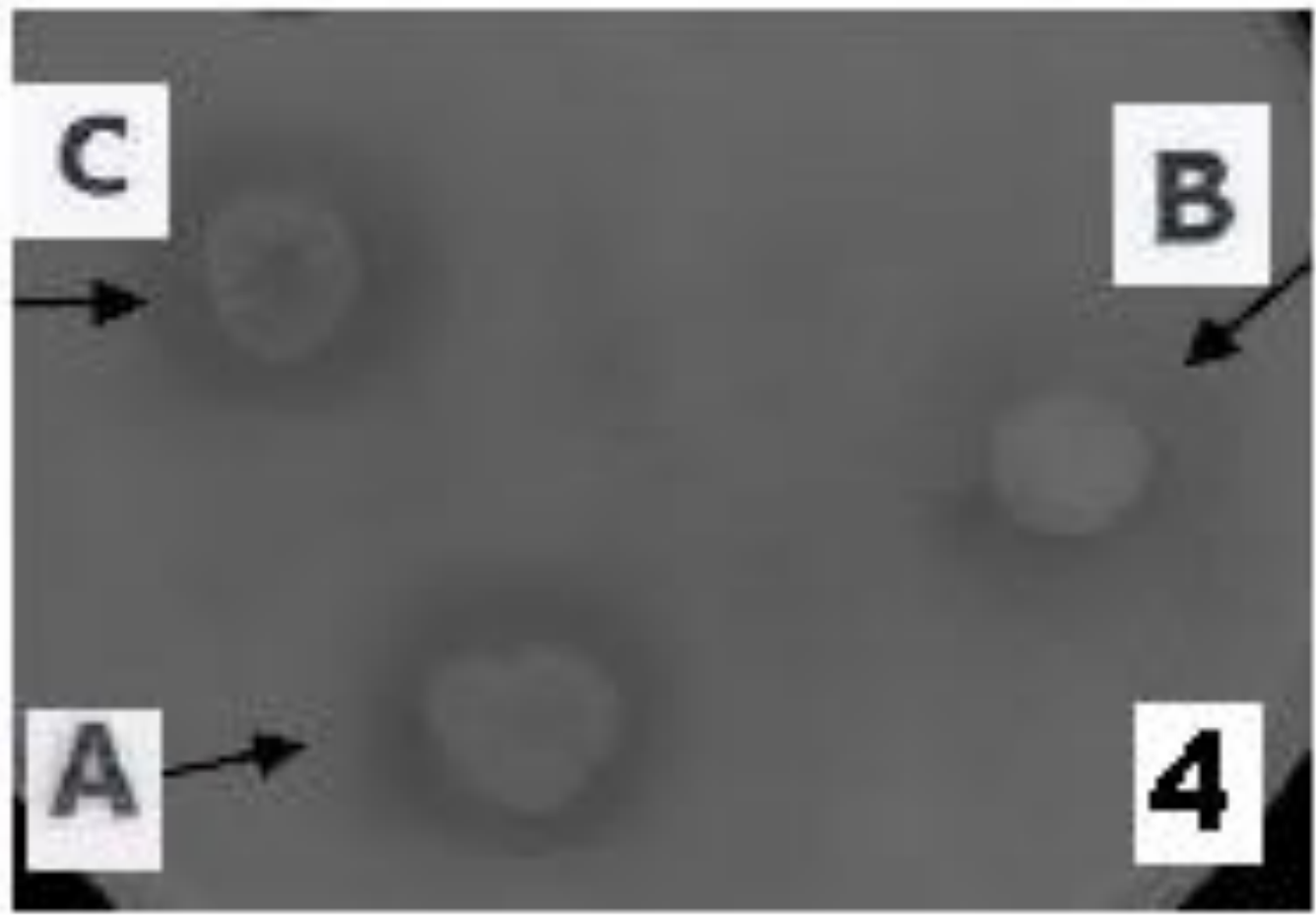


The processes of secondary metabolism (antibiotic production) and morphological differentiation (aerial mycelia formation and subsequent spore formation) in streptomycetes have been "linked" because both phenomena apparently occur simultaneously during the life cycle of these organisms. The coincidence of sporulation with the one onset of secondary metabolite production has been described by some as correlative relationship but not an interdependent one (Bu'lock, 1961; Schaeffer, 1969). Our results indicated that inhibitory metabolites production was not completely lost in the bald and SMs mutants generated by treatment with EB and NTG.

This would suggest that antibiotic production is likely chromosomally-encoded in this Streptomyces isolate used in this study. However, mutagenesis of a chromosomal gene could be responsible for this loss, since the dyes used could cause chromosomal aberrations.

This study showed the formation of bald mutants and loss of aerial mycelia $\left(\mathrm{amy}^{-}\right)$ after treatment of Streptomyces species with EB and NTG with maintaining the enzyme and antibiotic production activity.

\section{Acknowledgment}

Appreciation is extended to University of Sharjah/UAE and Jordan University of Science and Technology/Irbid-Jordan for administrative support.

\section{References}

Anderson, A. S., Wellington, E. M., 2001. The taxonomy of Streptomyces and related genera. Inter. J.Syst. Evol. Microbiol. 51, 797-814.

Baltz, R. H., Matsushim, P., 1983. Advance in protoplast fusion and transformation in
Streptomyces condition for efficient genetic recombination and cell regeneration. J. Gen. Microbial.127, 137-146.

Bauer, A.W., Kirby, W.M,, Sherris, J.C., Turk, M., 1966. Antibiotic susceptibility testing by a standardized single disk method. Am. J. Clinic. Pathol. 45, 493496.

Berdy, J., 1995. Are actinomycetes exhausted as a source of secondary metabolites? Proceeding of the nine symposiums on the actinomycetes. 13-34.

Bu'lock, J. D., 1961. Intermediary metabolism and antibiotic synthesis. Adv. Appl. Microbiol. 3, 293-342.

Delic, V., Hopwood, D. A., 1970. Mutagenesis by N-methyl-Nnitrosoguanidine (NTG) in Streptomyces coelicolor. Mut. Res. 9, 167-182.

Hopwood, D. A., Chater, K. F., Dowding, J. E., Vivian, A., 1973. Advances in Streptomyces coelicolor genetics. Bacteriol. Rev. 37, 371-405.

Hopwood, D. A., Bibb, M. J., Chater, K. F., Kieser, T., Burton, C. J., Kieser, H. M., Lydrate, D. J., Smith, C. P. Ward, J. M., Schrempf, H., 1985. Genetic Manipulation of Streptomyces. A Laboratory Manual. The John Innes Foundation, Norwich.

Hickey, R. J., Tresner, H. D., 1952. A cobaltcontaining medium for sporulation of Streptomyces species. J. Bacteriol. 84, 891-892.

Ikeda, H., Tanaka, H., Omura, S., 1981. Genetic and biochemical features of spiromycin biosynthesis in Streptomyces ambofaciens RM 265. J6. J. Antibiotics 35, 507-516.

Kato, J Chi W.,-J Ohnishi, Y., Hong S.,-K Horinouchi, S., 2005. Transcriptional control by A-factor of two trypsin genes in Streptomyces griseus. J. Bacteriol. 187, 286-295. 
Nanmori, T., Watatanabe, T., Shike, R., Korno, A., Kamamura, A., 1990. Purification and properties of thermostable xylanase and b-xylosidase produced by a newly isolated Bacillus stearothermoplilus. J. Bacteriol 172, (12) 6669-6672.

Priest, A., 1985. Extracelluar enzyme. Van nostrand reinhold (UK). 34, 45-67.

Redshaw, P. A., Mccann, P. A., Pentella, M. A., Pogell, B. M., 1979. Simultaneous loss of multiple differentiation in aerial mycelium-negative isolates of Streptomyces. J. Bacteriol. 137, 891899.

Redshaw, P. A., Mccann, P. A., Sankaran, L., Pogell, B. M., 1976. Control of differentiation in streptomycetes: Involvement of extrachromosomal deoxyribonucleic acid and glucose repression in aerial mycelium development. J. Bacteriol. 125, 698705 .

Saadoun, I., Elbetieha, A., Blevins, W. T., 1998. Activity of ethidium bromide (EB) and (NTG) on off-flavor compound-producing strain of Streptomyces. J. Bioscinces. 23, 595600.

Santos, E. O., Martins, L., Martins, M., 2003. Effect of the medium composition on formation of Amylase by Bacillus sp.
Brazil Arch Biol Technol. 46, 129-134. Schaeffer, P., 1969. Sporulation and the production of antibiotics, exoenzymes, and exotoxins. Bacteriol. Rev. 33, 4871.

Sermonti, G., Lanfaloni, L., Micheli, M. R., 1980, A jumping gene in Streptomyces coelicolor A3(2). Mol. Gen. Genet. 177, 453-458.

Sharma, P., Gupta, J. K., Dube, D. K., 1990. Purification and prosperities of Endoglucanase from a Bacillus isolate. Enzyme Microbiol. Technol. 12, 132137.

Vinogradova, S. P., Kushnir, S. N., 2003. Biosynthesis of hydrolytic enzymes during cocultivation of macro- and micromycetes. Appl Biochem Microbiol. 39, 573-575

Yamazaki, H., Ohnishi, Y., Horinouchi, S., 2003a. Transcriptional switch on of ssgA by A-factor, which is essential for spore septum formation in Streptomyces griseus. J. Bacteriol. 185, 1273-1283.

Yamazaki, H., Takano, Y., Ohnishi, Y., Horinouchi, S., 2003b. amfR, an essential gene for aerial mycelium formation, is a member of the AdpA regulon in the A-factor regulatory cascade in Streptomyces griseus. Mol. Microbiol. 50, 1173-1187.

\section{How to cite this article:}

Ismail Saadoun and Hazem Haddad. 2017. Effect of Ethidium Bromide (EB) and N-methyl-N'Nitro-N-Nitrosoguanidine (NTG) on Metabolic Activities of Streptomyces Strain N-404. Int.J.Curr.Microbiol.App.Sci. 6(7): 4231-4238. doi: https://doi.org/10.20546/ijcmas.2017.607.438 